\author{
ANASTASIA REIS \\ (D) https://orcid.org/0000-0003-4163-4109 \\ Carl von Ossietzky Universität \\ Oldenburg
}

\title{
O motywacji zmian językowych w zakresie fleksji mówionego języka łemkowskiego
}

\author{
On the motivation for linguistic changes with \\ regard to inflectional morphology of the spoken Lemko language
}

\begin{abstract}
The fact that the Lemko language is placed in the ethnolinguistic Western Slavic area next to the Polish language, which is dominant from the sociolinguistic point of view, has had and continues to have a significant impact on its development. Consequently, the Lemko language, similarly to other (Slavic) micro-languages, should be considered susceptible to changes resulting from the impact of exogenous factors, which can be observed even on a morphological level, which is generally perceived as particularly resistant to external influences. However, research conducted on the basis of material from the spoken corpus of the Lemko language shows that not all linguistic changes currently taking place in that language have been caused by the impact of Polish.
\end{abstract}

Key words: Lemko language, micro-language, inflectional morphology, linguistic change, ethnolinguistics

\section{Obecna sytuacja kontaktowa}

Wyodrębnianie „nowych” etniczno-narodowych lub etniczno-językowych wspólnot ze „starych”, już ugruntowanych konstruktów nie jest w dyskursie europejskim nowym fenomenem. W słowiańskim obszarze językowym w ostatnich dziesięcioleciach zwraca uwage głównie ruch rusiński. Rusini, których język - obok języka rosyjskiego, ukraińskiego i białoruskiego pierwotnie należał do jezzyków wschodniosłowiańskich i uważany jest za „narodowy” język tzw. Karpatorusinów, zajmują wśród etni wschodniosło- 
wiańskich szczególną pozycję. Ich terytorium w zachodniej części regionu karpackiego obejmuje z jednej strony część Podkarpacia na wschodzie, oddzieloną od ukraińskiego obszaru językowego głównym łańcuchem Karpat, z drugiej strony ciagnie się wydłużonym klinem przez cały Beskid Niski i sięga w głąb Zachodniej Słowiańszczyzny pomiędzy siedzibami Polaków na północy i Słowaków na południu, tworząc w ten sposób swoisty region przejściowy pomiędzy Słowiańszczyzną wschodnią i zachodnią․ Tym samym karpatorusiński w jego odmianach regionalnych w rozumieniu Heinza Klossa (1976) jest „zadaszony” przez wiele słowiańskich języków standardowych: słowacko-rusiński w regionie Preszowa przez język słowacki, rusiński na Podkarpaciu przez ukraiński, a łemkowski przez język polski.

Bliskie, trwające wiele stuleci sąsiedztwo języka rusińskiego z innymi językami słowiańskimi wpłynęło na jego rozwój leksykalny i strukturalny: rusińskie odmiany regionalne charakteryzują się licznymi „zapożyczeniami” m.in. z języków-dachów (niem. Dachsprache) na każdym poziomie językowym, włącznie z morfologicznym² (por. Magocsi 2006, 215).

Dzisiejszy kontakt łemkowskiego z innymi językami, który stanowi przedmiot tego artykułu, jest nie mniej intensywny. Ponieważ obszar zamieszkania Łemków znajduje się w Polsce, należy przypuszczać, że nie ma wśród nich jednojęzycznych użytkowników łemkowskiego, lecz z reguły są oni co najmniej dwujęzyczni i obok łemkowskiego władają także polskim na poziomie języka „ojczystego". W związku z tym kontakt z dominującym w ujęciu socjolingwistycznym językiem polskim, spełniającym w stosunku do łemkowskiego funkcję języka-dachu i wywierającym na niego (zwłaszcza na jego wariant mówiony) intensywny wpływ interferencyjny, można określić jako „socjalnie asymetryczny”. Wszystko to może doprowadzić do wariantywności na każdym poziomie językowym, do różnych zjawisk mieszania kodów czy w końcu do egzogenicznych, spowodowanych kontaktem zmian językowych (niem. kontaktinduzierter Sprachwandel).

${ }^{1}$ Ten, określany jako „praojczyzna” narodu rusińskiego, obszar sięga do terenów dzisiejszych Węgier i Rumunii. Niektóre rusińskie osady powstały w XVIII wieku także w Wojwodinie (na obszarze ówczesnej Jugosławii), por. Magocsi 2006, 207.

$2 \mathrm{~W}$ przypadku systemu (fleksyjno-)morfologicznego chodzi o taki poziom językowy, który powszechnie uważany jest za mało podatny na wszelkie wpływy wynikające z kontaktów z innymi językami (niezależnie od typologicznej bliskości języków wchodzących ze sobą w kontakt). A zatem w przypadku tego poziomu językowego każda egzogenicznie motywowana zmiana może zostać oceniona jako miarodajny wskaźnik świadczący o intensywności kontaktów zachodzących między językami (por. Menzel, Hentschel 2016). 
Ponadto z zachodniosłowiańskiego obszaru językowego również słowacki (przede wszystkim ze swoimi wschodniosłowackimi dialektami) można rozpatrywać jako będącą w kontakcie z łemkowskim odmianę językową. Jednak ten język zachodniosłowiański, ze względu na bezpośredni długotrwały historyczny kontakt „przez grzbiet karpacki” (Stieber 1938, 16 i n.; Stieber 1974, 474 i n.; Rieger 1992, 35 i n.) jest istotny szczególnie dla analizy starszych fenomenów kontaktowych. Ze względu na niejasny status genetyczny wschodniosłowackiego pomiędzy językami zachodnio- i wschodniosłowiańskimi nie da się wykluczyć, że pojedyncze strukturalne cechy łemkowskiego i dialektów wschodniosłowackich są ze sobą etymologicznie spokrewnione. Jako pokrewieństwo genetyczne należy także uznać możliwe formalne i strukturalne analogie do ukraińskiego - geograficznie najbliżej położonego języka wschodniosłowiańskiego - oraz jego południowozachodnich dialektów. Wprawdzie do kontaktów między łemkowskim i ukraińskim językiem standardowym doszło na skutek w przeważającej części narzuconej (por. Padjak 2006, 266 i n.; Michna 2004, 79 i n.) - polityki kulturalnej reżimu, jednak intensywność tych kontaktów, a co za tym idzie konsekwencji z nimi związanych, w poszczególnych regionach łemkowszczyzny jest bardzo różna ${ }^{3}$. W przypadku zachodniej części łemkowszczyzny, która jest przedmiotem niniejszych rozważań, nie zakłada się ani bezpośredniego kontaktu z dialektami ukraińskimi (w przeciwieństwie do północnowschodnich słowackich, a w szczególności do dialektów małopolskich), ani intensywnego i rozległego kontaktu z ukraińskim językiem standardowym ${ }^{4}$.

\section{Metodologia i materiał badawczy}

Celem artykułu jest próba uchwycenia aktualnych tendencji i czynników je wywołujących w rozwoju łemkowskiej fleksji. W przypadku łemkowskiego

\footnotetext{
${ }^{3}$ M.in. Mirosława Onyszkanycz-Kowalska (2002) stwierdza, że Łemkowie w Rzepedzi, a więc we wschodniej części Łemkowszczyzny, już w czasach przedwojennych mieli w różnych formach nieprzerwany kontakt z ukraińskim językiem standardowym (i mają go również dziś). Efektem tych kontaktów są, według autorki, różne realizacje łemkowskiego, które są hybryda z jednej strony łemkowskiego, a z drugiej ukraińskiego (i/lub polskiego). Charakter tego konstruktu nie został jednak bliżej objaśniony.

${ }_{4}^{4}$ Ten ostatni wypływa m.in. stąd, że etniczne samookreślenie Lemków w miejscach z zachodnich terenów Łemkowszczyzny (często w przeciwieństwie do jej obszarów na wschodzie) w znacznym stopniu nie zależy od ukraińskiego (por. Reis 2018b, 238 i n.). Więcej na temat zagadnienia i problematyki etnicznej i językowej tożsamości Rusinów por. m.in. Magocsi 2006, 211; Michna 2004, 283 i n.; Michna 2018.
} 
chodzi o tzw. „mikrojęzyk” albo „mały język”, czyli taki, którym posługuje się z reguły stosunkowo mała grupa etniczna i który $-\mathrm{z}$ powodu określonych konstelacji socjalno-politycznych - istnieje zawsze obok innego, dominującego w społeczeństwie prestiżowego języka (tu: języka polskiego). W tym kontekście szczególnie interesujące jest pytanie, jak mocno ukształtowany jest strukturalny wpływ dominującego języka polskiego na łemkowski, jaki charakter maja (możliwe) procesy zmian językowych na tle omówionych asymetrii dominacji i związanych z nimi zjawisk mieszania kodów.

Jakim preferencjom poddają się zatem małe języki w strukturalnie podobnym otoczeniu - czy na skutek tzw. „absolutnego” kontaktu językowego ${ }^{5}$ (por. Breu 2017) zyskuja popularność raczej elementy i struktury z dominującej odmiany języka mającej większy społeczny prestiż, jak to często ma miejsce w przypadku kontaktu pomiędzy językami niespokrewnionymi czy różniącymi się typologicznie odmianami języka (por. Thomason 2001, 2008)? Czy w przypadku łemkowskiego - pomimo niesprzyjającej sytuacji socjolingwistycznej - dają się zaobserwować raczej wewnątrzjęzykowe/wewnątrzdialektalne tendencje wyrównawcze (por. Kerswill, Trudgill 2005) lub rozpowszechnienie i ustalenie elementów i struktur „bardziej regularnych”, jak to często bywa właśnie w przypadku kontaktu między dialektami (por. Mayerthaler 1981; Wurzel 2001)?

Ponieważ nie jest całkiem jasne, w jakim zakresie wzorce fleksyjne, które są podane w quasi-kodyfikującej gramatyce języka łemkowskiego ${ }^{6}$, mają

5 Także w Borrowing Scale Sarah Thomason $(2001,70)$ intensywność procesów transferycznych (w zakresie leksykalnym i strukturalnym), które powstają na skutek kontaktu języków, jest zależna od intensywności tego ostatniego. W przypadku poziomu 1. i 2. (casual contact, slightly more intense contact) nie występuja zapożyczenia w sferze morfologii fleksyjnej, z kolei poziom 3. (more intense contact) charakteryzuje się już intensywnymi zapożyczeniami strukturalnymi (proces addytywny w tym przypadku polegać może np. na tym, że autochtoniczny leksem łączy się z zapożyczonym afiksem fleksyjnym). W przypadku ostatniego 4. poziomu (intense contact) zgodnie z mottem anything goes, nie ma praktycznie żadnych restrykcji dotyczących transferu w sferze morfologicznej, więc możliwe są nawet rozległe typologiczne zmiany (m.in. substytucja wzorów fleksyjnych przez wzory aglutynacyjne i odwrotnie; przejęcie lub zaniechanie kategorii gramatycznych; znaczne zmiany wzorów dystynkcyjnych itd.). Thomason podkreśla, że głównie te języki, które pod względem typologicznym są od siebie oddalone, dokładnie poddają się temu schematowi zapożyczeń, natomiast języki podobne do siebie pod względem strukturalnym ,are likely not to do so in all respects” (Thomason 2001, 71).

${ }^{6}$ Do tej pory miały miejsce dwie próby kodyfikacji łemkowskiego. Za pierwszą po zmianie politycznej można uznać wydaną nakładem własnym autorki Mirosławy Chomiak Пepuy граматьиу лемківского языка (Chomiak 1992). W 2000 roku opublikowana została obszerna praca Gramatyka jezylka temkowskiego / Iраматьюка лемківского язьљка Henryka Fontańskiego 
swoje potwierdzenie w języku mówionym (można wręcz zakładać, że pomiędzy rzeczywistym użyciem języka a inwentarzem form przewidzianych w łemkowskiej gramatyce istnieje pewien rozdźwięk, por. Reis 2013, 2018a i 2018c) $)^{7}$, za podstawę przedstawianych badań służy materiał z korpusu mówionego języka łemkowskiego. To oznacza, że przeanalizowany został wariant mówiony języka łemkowskiego, którym w rzeczywistości obecnie posługują się Lemkowie.

Odpowiadając na pytanie o ewentualne podobieństwo pomiędzy dwoma albo większą liczba języków w obszarze fleksyjnym na podstawie korpusu, zasadniczo należy brać pod uwagę co najmniej trzy różne typy cech: (1) formalne, czyli „formalno-substancjalne” (istnienie lub brak zgodności pomiędzy pojedynczymi formami czy sufiksami fleksyjnymi w odpowiednim paradygmacie porównywanych języków); (2) strukturalne, czyli „formalno-abstrakcyjne" (związki w obrębie paradygmatów, tzn. pewne wzory dystynkcyjne) oraz (3) kategorialne (por. Reis 2018b, 240 i n.). Problematyczne ze względów metodologicznych mogłoby się jednak okazać to, że w przypadku łemkowskiego ta sama (bądź inna) realizacja cech językowych często nie pozwala wskazać jednoznacznych zależności, gdyż formy łemkowskie

i Mirosławy Chomiak (2000), której drugie, poprawione wydanie od 2004 roku uznane zostało za kontrowersyjne (o różnicach między tymi dwoma wydaniami i o ustanawianiu normy pisanej por. Fontański 2008). Ta gramatyka ma jednak charakter raczej deskryptywny i dlatego może być określona jako quasi-kodyfikująca. Wynika to głównie z tego, że kwalifikujące się do pewnej pozycji paradygmatycznej i uchwycone przez kodyfikatorów formy fleksyjne (w wysokim stopniu wariantywnego) języka łemkowskiego zostały wcześniej poddane ,arbitralnej selekcji”. Tym samym w gramatyce podany został określony przez kodyfikatorów „,zestaw" form fleksyjnych, zweryfikowany na podstawie źródeł pisanych (przede wszystkim współczesnej literatury łemkowskiej) oraz na podstawie wyników ustnych oraz pisemnych ankiet przeprowadzonych na początku lat 90. Jednak dość często dla jednej pozycji paradygmatycznej podanych jest kilka form wariantywnych (czasami nawet do czterech różnych wariantów). Por. także krytyczny komentarz Aleksandra Duličenki (2009, 138).

${ }^{7}$ Materiały dla korpusu, który składa się z dwóch podkorpusów, zebrano odpowiednio w latach 1994-1996 oraz w latach 2010-2011. Korpus ten zawiera 196000 słowoform i obejmuje wypowiedzi 53 respondentów, pochodzących z 11 różnych miejscowości w zachodniej części terenu dawnej Łemkowszczyzny. Korpus został stworzony w ramach oldenburskiego projektu „Fleksyjne nieregularności we »współczesnych« odmianach kontaktowych języków północnosłowiańskich” (niem. „Flexionsmorphologische Irregularität(en) in »aktuellen« Kontaktvarietäten nordslawischer Sprachen"), realizowanego pod kierunkiem prof. dr. Gerda Hentschela (Oldenburg) przy wsparciu finansowym Niemieckiej Wspólnoty Badawczej (niem. Deutsche Forschungsgemeinschaft). Kolejne informacje dotyczące korpusu oraz respondentów podane są w: Menzel, Hentschel 2017. 
i polonizmy, ale także (mało)polskie i (wschodnio)słowackie dialektyzmy często mają tę samą postać. Zatem (synchroniczna) etymologiczna systematyzacja często nie jest możliwa dla blisko ze sobą spokrewnionych odmian językowych z wieloma ,intermorfami”, czyli tzw. „homofonicznymi diamorfami" (por. Hentschel 2018, 129 i n.). Poza tym wszystkie te odmiany charakteryzuje dość wysoki stopień zgodności inwentarza morfemów fleksyjnych, nawet jeśli dystrybucja wyznaczników fleksyjnych i wzorów synkretycznych wypada różnie.

Pytanie o obecne tendencje w łemkowskiej fleksji rozważane w tym artykule, odnosi się jednak w mniejszym stopniu do tego, czy zachodzi tu zasadniczo większe podobieństwo do słowiańszczyzny zachodniej, tzn. i do języka polskiego (niezależnie od tego, jaki charakter miałoby ono mieć - czy jest to skutek ścisłego pokrewieństwa, czy raczej dawnych, historycznych kontaktów językowych) ${ }^{8}$. Decydujące dla przedstawianych badań są aktualne zmiany językowe, wynikające $z$ obecnego kontaktu językowego. Ale jak można oddzielić jedno od drugiego? W tym miejscu warto dokładniej przyjrzeć się korpusowi. W przypadku „starszego” korpusu (StK) większość respondentów urodziła się między 1907 a 1927 rokiem, tym samym ich socjalizacja zachodziła w stabilnym łemkowskojęzycznym otoczeniu9. Natomiast

8 To, że łemkowski wskutek nieustającego kontaktu upodobnił się - głównie w obszarze leksykalnym i fonetyczno-fonologicznym - do języków zachodniosłowiańskich, jest udokumentowane w wielu opracowaniach. Już w latach 30. ubiegłego stulecia Zdzisław Stieber (1938/1974) zauważył ten fenomen i określił go jako „nieświadome przejmowanie cech obcych”. Efekty tych kontaktów są niekiedy tak dalekosiężne, że Alexander Teutsch w odniesieniu do rusińskiego na Słowacji stwierdził, że ten „czwarty wschodniosłowiański język” (Magocsi 1996) systemowo jest bardziej zbieżny z polskim i (wschodnio)słowackim, a więc z językami zachodniosłowiańskimi, niż ze wschodniosłowiańskim ukraińskim. Tak więc w przypadku słowacko-rusińskiego chodzi o odmianę początkowo wschodniosłowiańska, która wskutek nieustającego kontaktu z zachodniosłowiańskimi odmianami językowymi przejęła od nich wiele cech strukturalnych. Według Teutscha mamy tu do czynienia z przypadkiem praktycznego „zaniku” bliższego pokrewieństwa z językami wschodniosłowiańskimi i „powstania” nowego z jezzykami zachodniosłowiańskimi. Rezultatem tego procesu jest tworzenie się nowego kontinuum dialektalnego z przesunięciem granicy między słowiańszczyzną wschodnią a zachodnią dalej na wschód (por. Teutsch 2001, 220). Pierwsze opracowania w zakresie fleksji mówionego języka łemkowskiego prezentują częściowo podobne wnioski, por. Reis 2014, 2018a, 2018b, 2019.

${ }^{9}$ Z powodu przymusowych przesiedleń w latach 1945-46 do Związku Radzieckiego (przede wszystkim na Ukrainę) i później w 1947 roku („Akcja Wisła”) na tzw. nowe „ziemie zachodnie" (głównie na tereny dzisiejszych województw lubuskiego i dolnośląskiego) struktura terytorialna Łemków została w sposób znaczący zniszczona. Wprawdzie od 1956 roku istnie- 
respondenci „nowego” korpusu (NK) urodzili się przeważnie między 1940 a 1996 rokiem, co tym samym pozwala zakładać zdecydowanie większy wpływ języka polskiego. To znaczy, że podzielony materiał korpusu da się zinterpretować za pomoca metody badania zmian językowych w czasie pozornym, czyli apparent-time-studies (por. Labov 1994; Bailey 2004): u starszych użytkowników języka zaobserwować można wcześniejsze stadium rozwoju językowego w porównaniu do późniejszego, charakterystycznego dla młodszych użytkowników. To pozwala wskazać kontrasty między sposobem mówienia przedstawicieli różnych pokoleń z dwóch różnych przedziałów czasowych, tzn. synchroniczne różnice w znaczeniu zmiennych, czyli ich różna frekwencja u użytkowników w różnym wieku, będą rozumiane jako zmiany językowe w ujęciu diachronicznym. Takie podejście badawcze umożliwia również oddzielenie aktualnych fenomenów kontaktowych od refleksów starszych, historycznych kontaktów językowych (por. Reis 2018a).

Zmiany językowe w zakresie morfologii fleksyjnej mogą być jednak różnie motywowane. Należy - w miarę możliwości - rozgraniczyć czynniki (1) endogeniczne (w przypadku zmian wewnątrzjęzykowych) oraz (2) egzogeniczne (w przypadku zmian motywowanych kontaktem językowym). A więc wyniki analizy korpusu powinny być rozpatrywane również pod kątem założeń preferencyjno-teoretycznych, opracowanych w ramach morfologii naturalnej. Chodzi tu przede wszystkim o wariant „uniwersalny” z kryteriami izomorfizmu (tzn. uniformizmu i transparentności) i ikoniczności konstrukcyjnej według Mayerthalera (1981). W grę wchodzi również koncept naturalności „specyficzny dla danego języka” według Wurzla (2001), w którym naturalność „uniwersalna” uzupełniona jest czynnikiem bycia odpowiednim w stosunku do systemu danego języka.

Ponadto należy uwzględnić fakt, że nie każda endogeniczna zmiana motywowana jest wewnętrznie, tzn. wewnątrzmorfologicznie, co czyni ją prze-

je możliwość powrotu na pierwotne tereny zamieszkania, z której niektórzy Łemkowie skorzystali, jednak ich zdecydowana większość pozostała na obszarach przesiedlenia (więcej na ten temat Misiak 2006, 44 i n., 63 i n.; Magocsi 2004, 33 i n.). Z tego powodu w przypadku łemkowskiego trudno mówić o nietkniętej strukturze dialektalnej o typowo ustalonej charakterystyce przestrzennej, ponieważ ciagły rozwój języka łemkowskiego w jego tradycyjnym „krajobrazie kontaktowym” w 1947 roku został przerwany. W tym przypadku powinno się raczej założyć (przebyte) wewnątrzłemkowskie tworzenie się koiné, w którego konsekwencji drobne różnice dialektalne uległy zniwelowaniu (por. Michna 2004, 273; Menzel, Hentschel $2017,180)$. 
widywalną. Nie można wykluczyć, że przy zmianach wewnątrzjęzykowych rolę odgrywają również czynniki zewnętrzne, tzn. pozamorfologiczne (np. fonetyczno-fonologiczne lub syntaktyczne), które często prowadzą do idiosynkratycznych zmian.

W przypadku łemkowskiego, który znajduje się w „asymetrycznej” sytuacji kontaktu z językiem polskim, należy jednak zauważyć, że hipotezy uzasadniające jakiekolwiek zjawiska w kontekście zmian językowych tylko czynnikami wewnątrzjęzykowymi nie są tu wystarczające - w przypadku zmian językowych w łemkowskim rolę odgrywają nie tylko czynniki endogeniczne, ale również egzogeniczne. Oznacza to, że jeśli w korpusie da się zauważyć pewne ustabilizowanie wariantywności lub wyraźna preferencję użycia określonych form fleksyjnych, trzeba najpierw rozważyć pytanie, czy one nie są motywowane kontaktem językowym. Jeśli rzeczywiście zostanie przejęta jakaś forma fleksyjna charakterystyczna również dla silniejszego z socjolingwistycznego punktu widzenia języka - w tym przypadku języka polskiego - wówczas w następnym kroku należy sprawdzić, czy forma ta jest bardziej „regularna”, tzn. mniej nacechowana (bardziej zgodna $z$ uniwersalnymi lub specyficznymi dla danego języka zasadami naturalności niż „konkurencja”).

Jeśli zachodzi ten fenomen, wówczas nie można stwierdzić, który z dwóch czynników: egzogeniczny czy endogeniczny (wewnątrzmorfologiczny) wywarł tutaj wpływ, ponieważ preferencje strukturalne i socjolingwistyczne mogą zgodnie występować obok siebie. Ale preferencje określonych wzorów fleksyjnych mogłyby być również motywowane czynnikami czysto socjolingwistycznymi. W takim przypadku egzogenicznie motywowane zmiany językowe doprowadziłyby do przeważającej ekspansji form zgodnych z językiem dominującym w ujęciu socjolingwistycznym, nawet jeśli te ostatnie sa mniej korzystne z punktu widzenia podejścia preferencyjno-teoretycznego.

Także w sytuacji, gdy przyjmą się formy specyficzne, „autochtoniczne”, należy najpierw sprawdzić, czy nie chodzi tu o formy bardziej „regularne”. Jeśli tak, to zgodnie z argumentacja podejścia preferencyjno-teoretycznego zmiany te można ocenić jako motywowane przez czynniki endogeniczne, wewnątrzmorfologiczne. Jeśli preferencji form autochtonicznych, tzn. form specyficznie łemkowskich, nie da się wytłumaczyć z perspektywy morfologii naturalnej, wówczas zmiana w tym przypadku mogłaby być motywowana przez endogeniczne pozamorfologiczne czynniki. 


\title{
Analiza korpusu $^{10}$
}

\author{
Rzeczowniki rodzaju żeńskiego \\ w dopełniaczu, celowniku i miejscowniku liczby pojedynczej
}

$\mathrm{Na}$ temat statusu fonologicznego w języku łemkowskim trzech dźwięków: $|\mathbf{i}|(<\mathrm{y}>/<$ и $>)$ czy też $|\mathrm{Y}|(<\hat{\mathrm{y}}>/<\mathrm{d}>)$ oraz $|\mathrm{i}|(<\mathrm{i}>)$ toczą się żywe dyskusje ${ }^{11}$. Czy mamy tu do czynienia z trzema czy tylko $z$ dwoma fonemami, to kwestia natury zarówno empirycznej, jak i teoretycznej. Fonologia dialektalna łemkowskiego nie jest jednorodna i z punktu widzenia diachronicznego jest niestabilna. Z perspektywy empirycznej jest jednak jasne, że zakresy użycia obydwu „y” (-y- i $-\hat{y}-)$ ujednoliciły się, tzn. starsze, tylne $-\hat{y}-$ zostało prawie całkowicie wyparte przez środkowe $-y$ - wśród młodszych użytkowników języka12. Trudne do ustalenia jest jednak, czym są motywowane te zmiany, w jakim stopniu można interpretować je jako samoistny rozwój łemkowskiego albo refleks tendencji wyrównawczych z niwelowaniem wyrazistych cech dialektalnych (w rozumieniu Trudgilla 1986), a w jakim stopniu ten rozwój można rozpatrywać jako częściowe nakładanie się czynników endogenicznych fonetyczno-fonologicznych z czynnikami socjolingwistycz-

${ }^{10} \mathrm{~W}$ tym miejscu należy zaznaczyć, że w obu korpusach występują zjawiska mieszania kodów (w szerszym sensie). To znaczy, że spektrum wypowiedzi w nich zawartych sięga od „idealnych” polskich aż do takich, które nie zawierają żadnych polskich elementów i mogą zostać scharakteryzowane raczej jako „łemkowskie”. Używając terminologii Muyskena, to mieszanie w większości wypadków określić można jako code-mixing, tzn. wewnątrzzdaniowe mieszanie kodów. Ponadto w korpusie znaleziono również przykłady alternującego, międzyzdaniowego czy też międzywyrażeniowego przełączania kodów, w terminologii określanego jako code-switching. W ostatnim przypadku chodzi o zdania i syntagmy, których inwentarz fonemiczny i morfemiczny odpowiada polskiemu. Takie „polskie” (względnie „wspólne” polsko-łemkowskie) zdania i syntagmy nie były przedmiotem tej analizy. Analizie poddane zostały tylko zdania „łemkowskie” zawierające wszystkie możliwe typy mieszania kodów (w węższym sensie) według terminologii Muyskena (tzn. wewnątrzwyrażeniowe mieszanie, wtrącanie lub tzw. „kongruentną leksykalizację”), por. Muysken 2000.

11 Nawet ortograficzne przedstawienie tych (i innych) kontrastów zachodzących między głoskami nie jest jeszcze ustalone (por. Fontański 2008).

12 Poczatki tej tendencji zaobserwowal jeszcze w czasach przedwojennych Z. Stieber, który w pracach dialektologicznych w odniesieniu do fonologii łemkowskiej stwierdził, że młodszych użytkowników języka charakteryzuje tendencja do tej samej (tzn. raczej środkowej) wymowy prasłowiańskich $*_{i}$ i $*_{y}$, co w rezultacie prowadzi do zaniku pomiędzy nimi różnicy fonologicznej (por. Stieber 1982, 31-33). 
nymi, wynikającymi z obecnego kontaktu językowego (co najmniej w przypadku młodszych użytkowników języka łemkowskiego) ${ }^{13}$.

Konsekwencje takich zmian fonetyczno-fonologicznych są widoczne w różnych instancjach łemkowskiej fleksji i są niekiedy tak znaczne, że w niektórych paradygmatach fleksyjnych dochodzi nie tylko do zmian na płaszczyźnie formalnej, ale także do obszernej redystrybucji wzorów synkretycznych. Taka tendencja - jak obrazuje tabela 1. - zachodzi w przypadku rzeczowników deklinacji żeńskiej w D., C. i Ms. liczby pojedynczej.

Tabela 1. Dystrybucja końcówek rzeczowników deklinacji żeńskiej w D., C., Ms. lp w gramatyce i w korpusie języka łemkowskiego

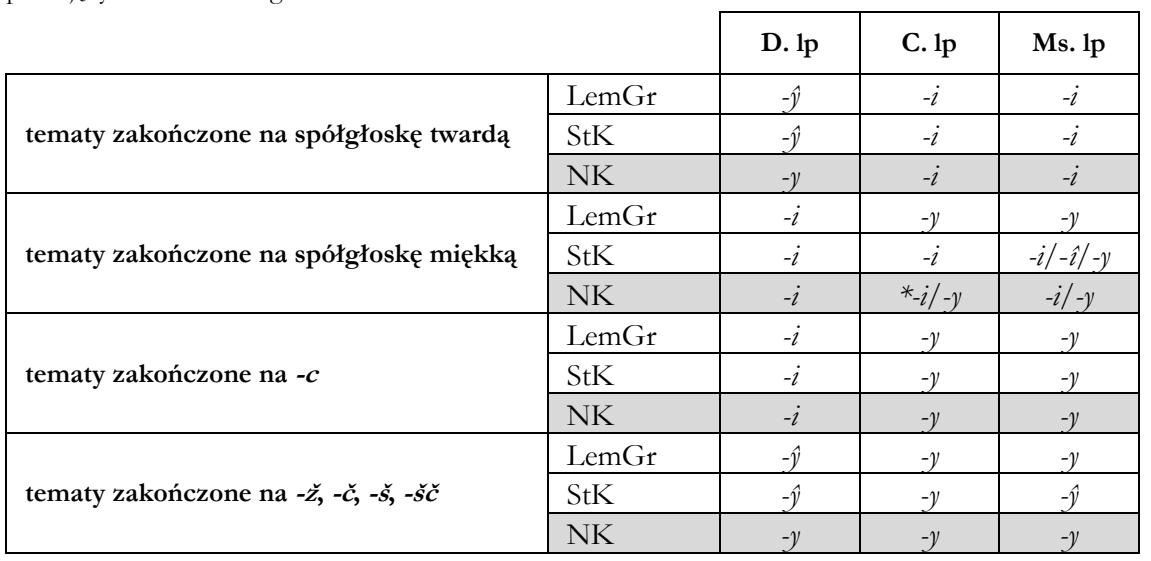

Jak ilustruje tabela 1., w gramatyce łemkowskiej w wymienionych przypadkach dla paradygmatu rzeczowników deklinacji żeńskiej w liczbie pojedynczej obowiązuje formuła D. $\neq$ C. = Ms. przy każdorazowo różnej, dość skomplikowanej formalnej realizacji w zależności od zakończenia tematu

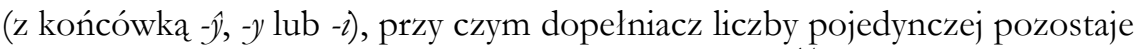
odmienny i nie tworzy żadnych relacji synkretycznych ${ }^{14}$.

13 Przykładem działania w tym kontekście czynników egzogenicznych (albo nakładania się ich z czynnikami endogenicznymi) jest przypadek narzędnika i miejscownika przymiotników rodzaju męskiego i nijakiego liczby pojedynczej (obszernie opisane w: Reis 2018c, 136 i n.) podobieństwo formalne do języka polskiego oraz charakterystyczny dla polskiego synkretyzm tych dwóch przypadków zaobserwowany u respondentów nowego korpusu jest (przynajmniej częściowo) spowodowany wpływem polszczyzny, por. dla przymiotników twardotematowych: starszy korpus: N. $(-\hat{y} m) \neq$ Ms. $(-i m)$ vs. nowy korpus: N. $(-y m)=$ Ms. $(-y m)$.

${ }^{14} \mathrm{~W}$ przypadku tematów zakończonych na $-j$ wszystkie trzy instancje wykazują homonimię D. = C. = Ms. z końcówką -i. 
Starszy korpus (w większym stopniu i częściej niż nowy korpus zgodny ze skodyfikowaną wersja) daje podobnie skomplikowany i stosunkowo niejednorodny obraz: w przypadku rzeczowników twardotematowych i zakończonych na spółgłoski welarne paradygmaty fleksyjne zgadzają się całkowicie z podanymi w gramatyce i wykazują homonimię C. = Ms. z końcówką -i.

Również w przypadku rzeczowników z tematem zakończonym na -c obowiązuje podany $\mathrm{w}$ gramatyce synkretyzm D. = Ms. z końcówką $-y$. Przy słowoformach $z$ tematem zakończonym na głoskę szumiącą obowiązuje synkretyzm D. = Ms. ze starą dialektalną końcówką $-\hat{y}$, natomiast w przypadku rzeczowników miękkotematowych (z niejasnymi związkami w miejscowni-

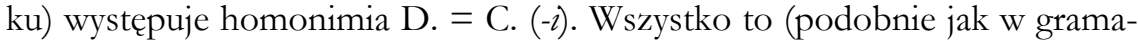
tyce) $z$ każdorazowo inna formalną realizacją.

Sytuacja u młodszych użytkowników języka przedstawia się całkowicie inaczej: z powodu jasnej preferencji i przejścia $\hat{y} \rightarrow y$ we wszystkich pozycjach paradygmatycznych, paradygmat deklinacji żeńskiej jest jasny i jednorodny z dwiema jedynie różnymi końcówkami. Rzeczowniki twardotematowe i o tematach zakończonych na spółgłoski welarne zachowują po fonetycznie uwarunkowanych zmianach schemat synkretyczny D. $(-y) \neq$ C. $=$ Ms. $(-\imath)$; w przypadku słowoform z wygłosem tematu na $-c$ ta „formuła” (przy podobnej realizacji formalnej) pozostaje diachronicznie stabilna.

Problematyczna pozostaje przy tym sytuacja paradygmatu rzeczowników miękkotematowych, w których zgodnie ze skodyfikowaną normą powinna obowiązywać homonimia C. = Ms. z końcówką $-y$. Wprawdzie podany w gramatyce $\mathrm{w}$ tym miejscu synkretyzm C. = Ms. ma swoje uzasadnienie (bo przecież jest on w przypadku rodzaju żeńskiego fenomenem ogólnosłowiańskim), to jednak uwidaczniają się w korpusie w Ms. lp dwie wariantywne końcówki -i i -y (w starszym korpusie w tej pozycji dodatkowo występuje jeszcze końcówka -̂ิ z dyftongiczną wymowa). Tej wariantywności również nie da się (jeszcze) rozstrzygnąć z perspektywy diachronicznej (por. Ms. lp

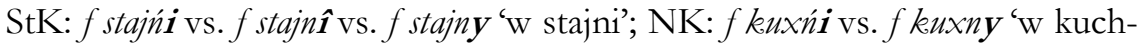
ni'). W związku ze stosunkowo rzadkim występowaniem celownika zrekonstruowanie schematu synkretyzmu przypadków przy tym typie tematu jest trudne. Dlatego rozwój może przybrać tu (co najmniej) dwa różne kierunki: końcówka -y mogłaby się przyjać w dwóch przypadkach, wówczas schemat C. $=$ Ms. $\neq$ D. miałby swoje zastosowanie (jak np. ma to miejsce w obecnym języku słowackim). Do takiej interpretacji skłania fakt, że po pierwsze w korpusie już się znajduja pojedyncze przykłady z końcówką -y w celowniku liczby pojedynczej, ale także to, że końcówka -y jest jednoznacznie prefe- 
rowana w Ms. lp przy rzeczownikach żeńskich zakończonych na spółgłoskę (np. NK: po časty 'po części', f starosty 'w starości', v oseny 'jesienia/w jesieni' itp.). Możliwe byłoby również wewnątrzparadygmatyczne wyrównanie z końcówką $-i(\mathrm{D} .=$ C. $=$ Ms.) we wszystkich przypadkach, jak to ma miejsce w językach polskim i ukraińskim. Opcja z odizolowanym miejscownikiem i schematem synkretycznym D. = C. $(-\imath) \neq$ Ms. $(-y)$ nie jest niemożliwa, jednak mniej prawdopodobna, zarówno z powodu swojej kompleksowości, jak i obowiązującej w językach słowiańskich przy rzeczownikach rodzaju żeńskiego homonimii C. = Ms.

W paradygmacie rodzaju żeńskiego z tematem zakończonym na $-\check{r},-\check{c},-5,-$ $\check{s c}$ dochodzi poprzez przejście $\hat{y} \rightarrow y$ nie tylko do zmian na płaszczyźnie formalnej, ale także do restrukturyzacji wzorów synkretycznych. Tu wszystkie przypadki upodobniły się do siebie, a w roli wspólnej końcówki występu-

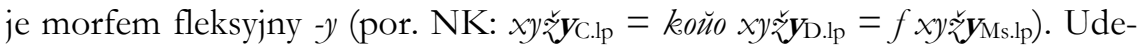
rzająca cechą tego zaobserwowanego w nowym korpusie kierunku rozwoju, bezpośrednio związanego z endogenicznymi zmianami fonetyczno-fonologicznymi, jest jednak to, że nie można go uważać za całkowicie oderwany od czynników egzogenicznych. Świadczy o tym schemat D. = C. = Ms. z końcówką $-y$ w rzeczownikach $z$ tematem zakończonym na głoskę szumiąca, który pokrywa się ze schematem obowiązującym dla języka polskiego. Jednakże stwierdzić można, że ten paradygmat w korpusie języka łemkowskiego nie wykazuje w sumie ani formalnych, ani strukturalnych podobieństw do paradygmatów języków sąsiadujących (por. Reis 2019).

Czasowniki w czasie teraźniejszym i przyszłym prostym w 3. os. Ip

Łemkowska koniugacja form czasu teraźniejszego i czasu przyszłego prostego opiera się ze swoimi trzema klasami koniugacyjnymi: I koniugacja (-es)', II koniugacja (-ǐ̌/-ys) i III koniugacja (-s) na polskim (więc na zachodniosłowiańskim) wzorcu. Wschodniosłowiańskie (standardowe) języki mają natomiast tylko dwie pierwsze klasy koniugacyjne ${ }^{15}$. Szczególnie interesujący

15 III klasa koniugacyjna powstała w języku polskim już w epoce przedpiśmiennej na skutek zaniku -j- w pozycji między samogłoskami w dawnej I koniugacji i dalszego upodobnienia i ściagnięcia tych grup głosek w czasownikach, które dziś zaliczane są do III koniugacji (aje $\rightarrow$ $\bar{a} \rightarrow$ a: po:̇egn-a-je $\rightarrow$ pożegn-a). Formy 1. os. lp przyjęły analogicznie do innych czasowników jak dam, wiem końcówkę - $m$, natomiast formy 3. os. lm zachowały ,archaiczny” kształt (por. Klemensiewicz 1985, 114). W niektórych polskich gramatykach koniugacja na - $m$, -sz podzie- 
jest tym samym rozwój w 3. os. lp, ponieważ to właśnie tu może dojść do potencjalnej „konkurencji” pomiędzy formami o zachodniosłowiańskim, czyli polskim charakterze z wschodniosłowiańskimi ze spółgłoską - $t$ w wygłosie ${ }^{16}$. W korpusie ta konkurencyjność jest widoczna w szczególności dla czasowników III koniugacji17. W przypadku obu korpusów stosunek form z końcówką - $\varnothing$ do form ze spółgłoską - $t$ w wygłosie (np. nasyya $\varnothing$ vs. nasyvat) prawie w ogóle się nie zmienia (por. tabela $2(\mathrm{a})$ ). W nowym korpusie zwiększa się użycie końcówki - $\varnothing$ zgodnie ze wzorcem polskim o $5 \%$, co stanowi dość niekorzystny obraz z „uporczywą” wariantywnością dwóch konkurujących ze sobą końcówek.

Tabela 2. Sufiksy fleksyjne w 3. os. lp czasu teraźniejszego koniugacji - $a \mathrm{w} \%$

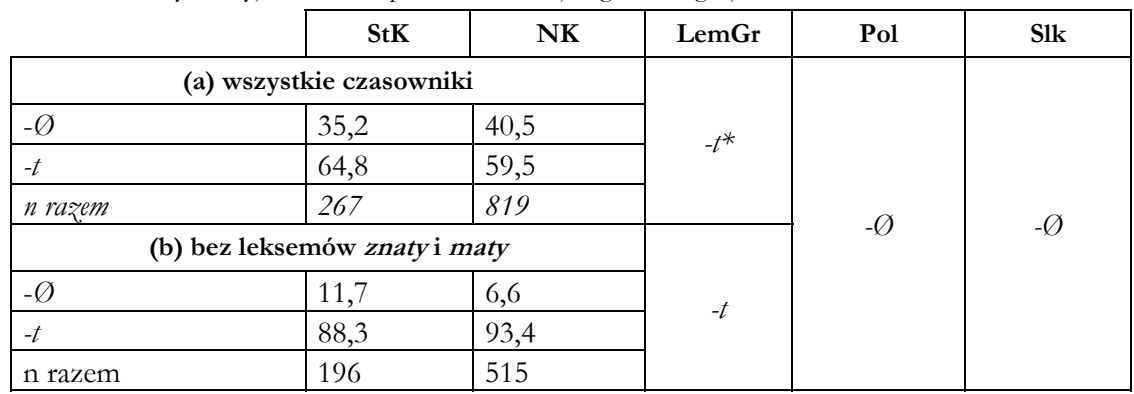

Po bardziej wnikliwej analizie danych z korpusu daje się jednak zauważyć, że znaczną część wszystkich przykładów z końcówką zerową stanowią leksemy żnaty 'znać / wiedzieć' i maty 'mieć' - dotyczy to obu korpusów $(75,5 \%$ w starszym i 89,8\% w nowym). Jeśli oba te leksemy wyłączy się z analizy,

lona jest na dwie klasy: -am, -asz (çytam, czytasz) oraz -em, -esz (wiem, wiesz). Rozróżnienie to wynika m.in. z różnego rozumienia granicy między tematem a końcówką fleksyjną. (W tym artykule pod pojęciem III koniugacji kryją się tylko te czasowniki, których temat kończy się na -a). We wschodniosłowiańskim obszarze takie ściagnięte formy czasowników spotkać można przede wszystkim w południowowschodnich ukraińskich i niektórych północnorosyjskich dialektach (bez spółgłoski - $t$ w wygłosie w ukraińskim, natomiast z takową występująca w rosyjskojęzycznym obszarze) (por. Žylko 1958, 67; Kuraszkiewicz 1963, 49, 71).

16 Podane w łemkowskiej gramatyce końcówki odpowiednich koniugacji (I: - $u,-e s$, , -e, -eme, ete, -ut; II: -u, -ǐs/-ys, -it/-yt, -ime/-yme, -ite/-yte, -at, III: -m, -s, -t, -me, -te, -ut) zgadzaja się w znacznym stopniu z udokumentowanymi w korpusie.

${ }^{17}$ Formy 3. os. lp I koniugacji charakteryzują się w łemkowskim, podobnie jak w innych wspominanych tu językach słowiańskich, końcówką samogłoskową (por. łem. ̌̌yje-pol. żyje - słow. rije - ukr. yyve). 
uwidacznia się (tabela 2b) jasny i przekonujący obraz dystrybucji z jednoznaczną preferencją (a nawet o lekkiej tendencji wzrastającej-5\%) łemkowskich form ,autochtonicznych” ze spółgłoską - $t$ w wygłosie:

StK: Gadam, ře jak kto kece, to f'sady śa nafýy̆d, tylko kto ne dbad o sfoje to... [Mówię, że jak ktoś chce, to wszędzie się nauczy, tylko kto nie dba o swoje, to...]

NK: Navet śa ne źv’idat, śade, jixat.

[Nawet się nie zapyta, siądzie, jedzie.]

Taki stan rzeczy jest nawet opisany w łemkowskiej gramatyce, która wprawdzie w przypadku 3. os. lp III koniugacji zaleca końcówkę -t, jednak dla leksemów znaty (wraz z prefiksalnymi derywatami) i maty podaje po trzy możliwe warianty: zna - znaje - znat i ma - maje - mat. Forma znat z zaledwie sześcioma wystapieniami ma w korpusie marginalny charakter, a forma * mat nie występuje w ogóle, więc wariantywność polega w głównej mierze na formach I koniugacji znaje/maje i ich „odpowiednikach” zna/ma z III koniugacji. Porównanie użycia tych form w obydwu korpusach pokazuje, że preferencja form zna/ma pozostaje niezmienna na poziomie $66 \%$.

Dokładny ogląd nowego korpusu i klasyfikacja danych według grup wiekowych (zob. rysunek 1.) ukazuje jednak pozornie całkiem nowa, a jednak wyraźną tendencję wzmacniania dominacji form zna/ma, czyli przejście leksemów znaty/maty z koniugacji I do III w przypadku najmłodszych, urodzonych po 1985 roku użytkowników języka (83,4\%), chociaż przełom w użyciu tych form (z 46,1\% na 73,4\%) można odnotować już pomiędzy dwoma pierwszymi grupami wiekowymi nowego korpusu.

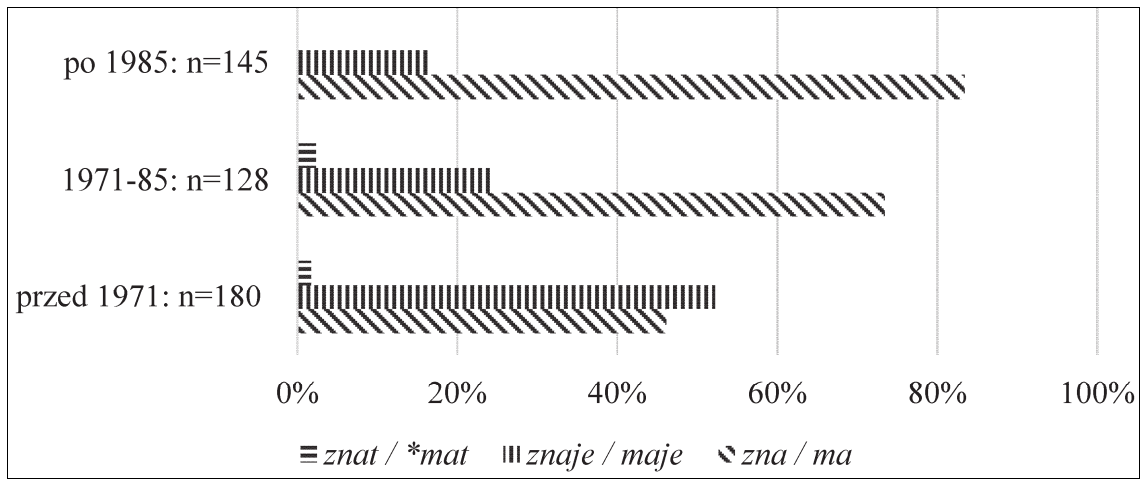

Rysunek 1. Formy 3. os. lp czasu teraźniejszego czasowników znaty/maty w nowym korpusie według wieku (razem n $=453)$ 
Tym samym w przypadku 3. os. lp czasu teraźniejszego III koniugacji da się zauważyć jednoznaczne zasady dystrybucji form fleksyjnych: łemkowskie autochtoniczne formy ze spółgłoską -t w wygłosie dominują wyraźnie z 93,4\% nad formami z końcówką zerową. Tylko w przypadku często występujących form znaty/maty, które poddane są egzogenicznym zmianom, repartycja końcówek następuje zgodnie z polskim wzorem.

Nowy Korpus:

> 1985: (...) no ale ma totu jakuś tam dźĕŭcynu, jakuśpjerun zna otkal... [... no, ale ma tę jakąś tam dziewczynę, jakąś pieron wie skąd...]

< 1970: No juś śa na t’im znaje, bo śa juś tyma aŭtamy robyt. [On już zna się na tym, bo <tyle lat> już przy tych autach robi.]

< 1970: Ni, ńi bo śa bojaŭ, že ne puśćat ho spowrotom, bo v'in ne maje vizy.

[Nie, nie, bo bał się, że go nie puszczą z powrotem, bo nie ma wizy.]

< 1970: (...) fkaždy groxufí ma byty majoranek...

[...w każdej grochówce ma być majeranek...]

Taki rozkład, jeśli rozpatruje się go pod kątem regularności, nie jest niczym niezwykłym. W językach z morfologia fleksyjną zwłaszcza wyrazy o dużej częstotliwości występowania charakteryzują się pewną różnorodnością form fleksyjnych. Podejścia preferencyjno-teoretyczne, które koncentrują się przede wszystkim na produkcji mowy, są często w konflikcie $\mathrm{z}$ nieregularnościami zorientowanymi na ekonomię $\mathrm{w}$ sferze percepcji, które sprzyjają formalnemu różnicowaniu się form o dużej częstotliwości. W przypadku ekstremalnie często używanych leksemów należy się nawet spodziewać fleksyjno-morfologicznej nieregularności, ponieważ formalnie kontrastujące struktury sa percepcyjnie łatwiejsze do uchwycenia niż „regularnie" odmieniane formy (por. Werner 1987).

Co się zaś tyczy roli częstotliwości w zmianach fleksyjnych, Hentschel (1992) pokazuje wyraźnie na przykładzie języków rosyjskiego i polskiego, że zwłaszcza w początkowej fazie przemian (a właśnie z taką mamy najwyraźniej do czynienia w przypadku łemkowskich czasowników III koniugacji) są to przede wszystkim leksemy o dużej częstotliwości, które już przybierają nową końcówkę. Słowa będące w częstym użyciu wykazują zasadniczą tendencję, aby wyraźnie odcinać się od reszty, co manifestować się może w sposób innowacyjny we wczesnej fazie pojawiania się nowej końcówki fleksyjnej lub przeciwnie może znajdować swój wyraz (w przypadku dalece zaawansowanych zmian jezzykowych) w konserwa- 
tywnym zastygnięciu starych (czy też archaicznych) końcówek (por. Hentschel 1992, 58) ${ }^{18}$.

Dlatego też i w tym przypadku zachowanie będących w częstym użyciu leksemów znaty i maty może zostać odczytane jako wskaźnik dopiero nadchodzacych zmian fleksyjnych w paradygmacie czasu teraźniejszego III koniugacji (niezależnie od kierunku, w którym ewentualne zmiany miałyby się dokonać).

Zatem czynniki egzogeniczne, czy - inaczej mówiąc - wpływ języka polskiego na 3. os. lp czasu teraźniejszego, nie mają (przynajmniej jeszcze obecnie) szerokiego odbicia. Jest to godne uwagi tym bardziej, że w kontekście rozpatrywania wszystkich typów koniugacji wzór fleksyjny socjolingwistycznie dominującego polskiego jest nawet bardziej jednolity, tzn. regularny niż łemkowski. Polski paradygmat czasu teraźniejszego/przyszłego w 3. osobie charakteryzuje się nieprzerwanie samogłoskowymi końcówkami (w lp I: $-e$; II: -i/-y; III: -Ø z samogłoskowym wygłosem tematu; w lm -ô), z tym że komponent nosowy w lm przyczynia się do ikonicznej relacji między dwiema liczbami gramatycznymi, a tym samym do regularności. W tym sensie bardziej regularny wzór fleksyjny w języku polskim kontrastuje z bardzo złożonym wzorem dystrybucji w języku łemkowskim (w lp - I: -e, II: -it/-yt, III: - $t$ vs. -Ø w przypadku związania leksykalnego; w $\operatorname{lm}-u t /-a t)$.

\section{Podsumowanie, wnioski i perspektywy}

Dzięki metodzie badań zmian językowych w czasie pozornym (apparent time studies) i porównaniu na jej podstawie materiału językowego starszych i młodszych użytkowników języka, możliwe było dojście do różnych wniosków odnośnie do diachronicznego rozwoju struktur fleksyjnych we współczesnym mówionym języku łemkowskim. Na podstawie wielu zaprezentowanych przeanalizowanych przykładów da się uchwycić pewne ogólne tendencje.

${ }^{18}$ Hentschel $(1992,50)$, twierdząc, że leksemy o dużej częstotliwości użycia mogą być zarówno „prekursorem”, jak i „zamykającym elementem” zmian morfologicznych, a z kolei większość nie tak często występujących słów zajmuje z punktu widzenia chronologii pozycję środkowa, jednoznacznie sprzeciwia się ogólnej tezie (por. Hooper 1976; Mańczak 1980), że zmianom fleksyjnym ulegają najpierw wyrazy o małej, a dopiero później o dużej częstotliwości występowania. 
Natura dających się zaobserwować w mówionym języku łemkowskim fenomenów związanych ze zmianami we fleksji jest bardzo heterogenna. Prymat egzogenicznych, socjolingwistycznych czynników obowiązujący głównie w przypadku języków typologicznie od siebie oddalonych, o którym mówi Thomason (por. Thomason 2001, 71; 2008, 43 i n.), nie sprawdza się (przynajmniej na razie) w przypadku języka łemkowskiego. Nie zmienia tego nawet fakt, że kontakt języków łemkowskiego i polskiego da się zakwalifikować jako kontakt od 3. (more intense contact) do 4. stopnia (intense contact) intensywności w tzw. „skali zapożyczeń” (borrowing scale, Thomason 2001, 70 i n.), co powoduje, że - szczególnie w przypadku strukturalnych podobieństw języków będących w kontakcie - praktycznie nie istnieją jakiekolwiek restrykcje zapożyczeń na poziomie fleksyjnym (por. Thomason 2015, 32) ${ }^{19}$. Co prawda zmiany we fleksji łemkowskiej, ukierunkowane na zbliżenie z polszczyzną, dotyczą zarówno obszaru formalnego, jak i strukturalnego ${ }^{20}$ (m.in. przez przejęcie polskich wzorów synkretycznych), jednakże formalne zgodności z polskim daje się z reguly zaobserwować w przypadku rozbieżnej struktury paradygmatycznej, natomiast zgodne struktury paradygmatyczne charakteryzują się często odmienną realizacją formalną (por. Reis 2018a, 2018b; Menzel, Reis 2014, 155). Przypadki, kiedy zbliżenie do języka polskiego ma miejsce jednocześnie w ujęciu formalnym i strukturalnym (jak pokazują to np. wspomniane wyżej przykłady z paradygmatu przymiotnikowego), należą raczej do wyjątków i nie da się ich ograniczyć tylko do wpływu egzogenicznego.

Ponadto z przeanalizowanych przykładów nie wynika dominacja preferencji opartych na założeniach teorii naturalności: w niektórych przypadkach można zaobserwować stabilność łemkowskich form i struktur rodzimych również tam, gdzie z punktu widzenia morfologii naturalnej nie są one optymalne, podczas gdy formy fleksyjne (czy też wzory fleksyjne) społecznie dominującego języka polskiego są korzystniejsze z punktu widzenia podejścia preferencyjno-teoretycznego. Co więcej, zaprezentowane tu przykłady i dotychczasowe wyniki wskazuja na złożone powiązania egzogenicznych i endogenicznych (wewnątrzmorfologicznych i pozamorfologicznych) czyn-

${ }^{19}$ Dwujęzyczność także wzmacnia intensywność kontaktów między językami (por. Thomason 2015, 34).

20 Wpływ polskiego na język łemkowski w ujęciu kategorialnym (polegający głównie na przejęciu lub ewentualnie zachowaniu rodzaju męskoosobowego) wymaga dalszych badań. O wynikach badań dotyczących zaimków anaforycznych por. Menzel, Reis 2014, 133 i n.; o rzeczownikach, atrybutach przymiotnikowych i czasownikach por. Reis 2019. 
ników. Godne uwagi jest to, że w tych przypadkach, kiedy daje się zaobserwować zmianę fleksyjno-morfologiczna, zazwyczaj zachodzi większa liczba preferencji, tzn. strukturalne i socjolingwistyczne czynniki występują często równocześnie lub - innymi słowy - wzmacniają się wzajemnie. „Polskie” końcówki znajdują zatem z reguły swoje zastosowanie we fleksji języka łemkowskiego, kiedy sprzyjają temu struktury paradygmatyczne.

Poza tym można zaobserwować, że skuteczność czynników egzogenicznych jest w języku łemkowskim w szczególności decydująca dla rzeczownikowego obszaru fleksji, gdy tymczasem obszar czasownikowy (ze związanymi morfemami fleksyjnymi) pozostaje dość odporny na wpływ silniejszej socjolingwistycznie polszczyzny. Ciekawe, że wniosek ten jest zbieżny z wnioskami, do jakich dochodzą Menzel i Hentschel (2015), badający morfologię fleksyjną mieszanej białorusko-rosyjskiej mowy (MBRM, tzw. trasianki) oraz mieszanej ukraińsko-rosyjskiej mowy (MURM, tzw. surżyka) na Białorusi czy Ukrainie. Również tu da się w paradygmacie czasowników w przeciwieństwie do rzeczowników wykazać znacznie mniej (w przypadku MBRM) albo bardzo mało (w przypadku MURM) ${ }^{21}$ przykładów „rosyjskich" końcówek, a tym samym brak tu dowodów na zdecydowany wpływ dominującego języka rosyjskiego ${ }^{22}$. W przypadku tych morfemów fleksyjnych chodzi jednak w przeważającej mierze o leksykalnie utrwalone zapożyczenia, które współwystępuja z rosyjskimi lub wspólnymi tematami wyrazów, co potwierdza szeroko uznaną tezę, że zapożyczone końcówki występują najpierw tylko z zapożyczonymi leksemami (Thomason, Kaufmann 1988, 74 i n.), a rzeczowniki są o wiele częściej zapożyczane niż czasowniki (Matras 2015, 59 i n.; Thomason 2001, 70). Takie ustalenie podobieństwa w odniesieniu do każdego morfemu, które zostało przeprowadzone w przy-

21 Te niewielkie różnice między MBRM i MURM dotyczące „podatności” na wpływ języka rosyjskiego można wytłumaczyć głównie tym, że język rosyjski na Białorusi pod względem społecznym dominuje nad białoruskim o wiele silniej niż nad językiem ukraińskim na Ukrainie (por. Menzel, Hentschel 2015, 125). Ale też fakt, że strukturalny dystans pomiędzy rosyjskim i białoruskim (w porównaniu do tego między językiem rosyjskim a ukraińskim) jest mniejszy, pozostaje w tej kwestii również nie bez znaczenia.

22 Również w przypadku przymiotników (włączając zaimki i liczebniki o deklinacji przymiotnikowej) okazuje się, że wpływ rosyjskiego jest niewielki (por. Menzel, Hentschel 2015, 153). W przypadku języka łemkowskiego są to jednak przede wszystkim czasowniki z morfemami związanymi, które (jeszcze?) w dużej mierze pozostają odporne na wpływ socjolingwistycznie dominującej polszczyzny, chociaż zmiany językowe zachodzące we fleksji przymiotnikowej w porównaniu ze zmianami w rzeczownikach nie są tak obszerne (por. Reis 2019). 
padku MBRM oraz MURM 23 , jest w przypadku łemkowskiego - z powodu niepełności źródeł leksykograficznych (por. Káprály 2013, 92 i n.) i bardzo „niewiążących” stosunków pomiędzy wariantem mówionym a zaproponowaną kodyfikacja - z pewnością niemożliwe ${ }^{24}$. Jednakże dla pozostałych instancji zmian fleksyjnych należałoby sprawdzić, czy da się sporządzić „hierarchię zapożyczeń” na poziomie fleksji związanej również w zależności od części mowy, w której te zmiany występują.

Zasadniczo porównanie korpusów ukazuje jasną tendencję do ujednolicenia procesów tworzenia form, do rozległej redukcji wariantywności konkurencyjnych form, a tym samym do eksplikacji wyraźnych preferencji pewnych wzorów fleksyjnych i stopniowego ustalenia się uzusu gramatycznego (w pewnym stopniu rozbieżnego z zaproponowaną normą skodyfikowana). Wyniki badań potwierdzają zatem konstytuowanie się wewnątrzdialektalnych form wyrównawczych (m.in. poprzez zanik różnic międzydialektalnych) oraz niwelowanie rzadko występujących form w wyniku ,wewnątrzłemkowskiego" tworzenia się koiné.

Ttum. Joanna Sulikowska-Fajfer i Anastasia Reis

\section{Literatura}

Bailey G., 2004, Real and Apparent Time, in: Chambers J.K., ed., The Handbook of Language Variation und Change, Malden.

Breu W., 2017, Moliseslavische Texte aus Acquaviva Collecroce, Montemitro und San Felice del Molise, in: Breu W. et al., Hrsg., Slavische Mikrosprachen im absoluten Sprachkontakt. Glossierte und interpretierte Sprachaufnahmen aus Italien, Deutschland, Österreich und Griechenland, Bd. 1, Wiesbaden (Slavistische Beiträge 505).

Chomiak M., 1992, Gramatŷka lemkivskoho jazŷka, Legnica.

Duličenko A.D., 2009, Das Russinische, in: Rehder P., Hrsg., Einfübrung in die slavischen Sprachen, 6. Aufl., Darmstadt.

Fontański H., 2008, Aktualne problemy jezylka temkowskiego (normalizacja pisowni), w: Pljiškova A., red., Rusyns'kŷjj jasŷk meḍ̌i dvoma kongresamy. Zbornik referativ z. III. Medžinarodnoho kongresu rusyns'koho jasyjka, Krakiv, 13.-16.9.2007, Prjašiv.

Fontański H., Chomiak M., 2000, Gramatyka jezyka temkowskiego. Iраматыка лемківского языюка, Katowice.

Hentschel G., 1992, Verwendungshäufigkeit und Innovation im Flexionssystem - Beobachtungen zum morphologischen Wandel im Russischen und Polnischen, „Zeitschrift für Slawistik“, Nr. 37.

23 Więcej o tych badaniach zob. m.in. Hentschel 2013, 62 i n.

24 Por. również Menzel, Hentschel 2017, 102 i n. 
Hentschel G., 2013, Belorusskij, russkij i belorussko-russkaja smešannaja rě́, „Voprosy jazykoznanija”, nr 1, 53-76.

Hentschel G., 2018, Die weißrussische „Trasjanka“ und der ukrainische „Sur:yyk": grundlegende quantitativ-qualitative soziolinguistische Ähnlichkeiten und Unterschiede, in: Kempgen S. et al., Hrsg., Deutsche Beiträge zum 16. Internationalen Slavistenkongress, Belgrad 2018, Wiesbaden (Die Welt der Slaven. Sammelbände. Sborniki 63).

Hooper J.B., 1976, An Introduction to Natural Generative Phonology, New York.

Káprály M., 2013, Sovremennye rusinskie literaturnye mikrojazyki, „Studia Slavica Hungarica”, nr 58(1).

Kerswill P., Trudgill P., 2005, The Birth of New Dialects, in: Auer P. et al, eds., Dialect Change: Convergence and Divergence in European Languages, Cambridge.

Klemensiewicz Z., 1985, Historia jezyka polskiego, cz.1., Warszawa.

Kloss H., 1976, Abstandsprachen und Ausbausprachen, „Zeitschrift für Dialektologie und Linguistik. Beihefte. Neue Folge", No. 16.

Kuraszkiewicz W., 1963, Zarys dialektologii wschodniostowianskiej z wyborem tekstów gwarowych, Warszawa.

Labov W., 1994, Principles of Linguistic Change, vol. 1, Internal Factors, Oxford.

Magocsi P.R., 1996, The Rusyn Language Question Revisited, in: Magosci P.R., ed., A New Slavic Language is Born. The Rusyn Literary Language of Slovakia, New York.

Magocsi P.R., 2004, Etno-geografičnyj i istoričnyj perebljad, in: Magocsi P.R., ed., Rusinskyj jasyk, Opole.

Magocsi P.R., 2006, Rusinskij jasyk: dostǐ̌enija poslednego vremeni i predstojaščie qadaŭi, in: Duličenko A.D., Gustavsson S., eds., Slavjanskie literaturnye mikrojazyki i jazykovye kontakty, Tartu.

Mańczak W., 1980, Frequenz und Sprachwandel, in: Lüdtke H., Hrsg., Kommunikationstheoretische Grundlagen des Sprachwandels, Berlin-New York.

Matras Y., 2015, Why is the Borrowing of Inflectional Morphology Dispreferred?, in: Gardani F., Arkadiev P., Amiridze N., eds., Borrowed Morphology, Berlin.

Mayerthaler W., 1981, Morphologische Natürlichkeit, Wiesbaden.

Menzel T., Hentschel G., 2015, Zum Einfluss des Russischen auf die Flexionsmorphologie der weißrussisch-russischen und ukrainisch-russischen gemischten Rede, „Wiener Slawistischer Almanach”, Nr. 75.

Menzel T., Hentschel G., 2016, Zu Pronominalparadigmen in Kontaktvarietäten. Demonstrativpronomen in der gemischten weißrussisch-russischen Rede in Weißrussland, in: Bittner A., Köpcke K.-M., Hrsg., Regularität und Irregularität in Phonologie und Morphologie. Diachron, kontrastiv, typologisch, Berlin.

Menzel T., Hentschel G., 2017, Flexionsmorphologische Irregularität im innerslavischen Sprachkontakt. Sprachinbärente Präferenzen oder politisch-soziale Dominanz: Russisch vs. Weißrussisch/ Ukrainisch Polnisch vs. Kaschubisch/ Lemkisch, Frankfurt a.M.

Menzel T., Reis A., 2014, Regularität / Irregularität im Paradigma anaphorischer Pronomen: Zur Rolle des Sprachkontakts im Lemkischen, „Zeitschrift für slavische Philologie”, Nr. 70/1.

Michna E., 2004, Kwestie etniczno-narodowościowe na pograniczu Stowianszçyzny wschodniej $i$ zachodniej. Ruch rusinski na Stowacji, Ukrainie i w Polsce, Kraków.

Michna E., 2018, Ideologie jezykowe i ich wplyw na procesy emancypacji jezyka temkowskiego, w: Tambor J., red., Polonistyka na poczatku XXI wieku. Diagnozy, koncepcje, perspektywy, t. 4., Pogranicza, mniejszości, regiony. Etnolingwistyka, Katowice. 
Misiak M., 2006, Łemkowie. W kregu badań nad mniejszościami etnolingwistycznymi w Europie, Wrocław. Muysken P., 2000, Bilingual Speech. A Typology of Code-mixing, Cambridge.

Onyszkanycz-Kowalska M., 2002, Sytuacja gwary temkowskiej i ukrainskiego jesyka literackiego w Rzepedzi, w: Rieger J., red., Jezylk mniejszości w otoczeniu obcym, Warszawa.

Padjak V., 2006, Zakarpat'e (Podkarpatskaja Rus'): problemy i osobennosti funkcionirovanija rusinskogo literaturnogo jazyka v kontekste nacional'nogo vozroždenija, in: Duličenko A.D., Gustavsson S., eds., Slavjanskie literaturnyemikrojazyki i jasykovye kontakty, Tartu.

Reis A., 2013, Lemkovskie anaforičeskie mestoimenija: kodificirovannaja norma i razgovornyj uzus, „Linguistica Copernicana”, nr 1(9).

Reis A., 2014, Jazyle lemkov na granice meždu Vostočnoj i Zapadnoj Slaviej: osobennosti slovoizmenenija anaforičeskich mestoimenij v reči lemkov, in: Giger M. et al., eds., Slované mezi tradici a modernitou, Praha.

Reis A., 2018a, Kontakt jezykowy a zmiana systemu fleksyjnego: wplyw polszczyzny na jezyk temkowski, w: Tambor J., red., Polonistyka na poczqtku XXI wieku. Diagnozy, koncepcje, perspektymy, t. 4., Pogranicza, mniejszości, regiony. Etnolingwistyka, Katowice.

Reis A., 2018b, Zur Rolle von „Entlehnungen“ und „Kalkierungen“ in der lemkischen Flexionsmorphologie, in: Witzlack-Makarevich K., Hrsg., Kalkierungs- und Entlehnungssprachen in der Slavia: Boris Unbegaun zum 120. Geburtstag, Berlin.

Reis A., 2018c, Flexionsmorphologischer Wandel im Lemkischen: endogene und exogene Faktoren, in: Kempgen S. et al., Hrsg., Deutsche Beiträge zum 16. Internationalen Slavistenkongress in Belgrad 2018, Wiesbaden.

Reis A., 2019, [nieopublikowana praca doktorska], Endogener und exogener flexionsmorphologischer Wandel in Kleinsprachen: Der Fall des Lemkischen zwischen Polnisch, Slovakisch und Ukrainisch, Oldenburg.

Rieger J., 1992, Typy kontaktów jezykowych w Karpatach, w: Siatkowski J., Doliński I., red., Stowiansko-niestowianskie kontakty jezykowe, Warszawa.

Stieber Z., 1938, Sposoby powstawania stowianskich gwar præejsciowych, Kraków.

Stieber Z., 1974, Wplyw polski i stowacki na gwary Lemków, w: Stieber Z., Świat jezykowy Stowian, Warszawa.

Stieber Z., 1982, Dialekt Łemków. Fonetyka i fonologia, Wrocław.

Teutsch A., 2001, Das Rusinische der Ostslowakei im Kontext seiner Nachbarsprachen, Frankfurt.

Thomason S.G., 2001, Language Contact. An Introduction, Edinburgh.

Thomason S.G., 2008, Social and Linguistic Factors as Predictors of Contact Induced Change, ,Journal of Language Contact - THEMA", no. 2.

Thomason S.G., 2015, When is the Diffusion of Inflectional Morphology Not Dispreferred?, in: Gardani F., Arkadiev P., Amiridze N., eds., Borrowed morphology, Berlin.

Thomason S.G., Kaufmann T., 1988, Language Contact, Creolization, and Genetic Linguistics, Berkeley.

Trudgill P., 1986, Dialects in contact, Oxford.

Werner O., 1987, Natürlichkeit und Nutzen morphologischer Irregularität, in: Boretzky N. et al., Hrsg., Beiträge zum 3. Essener Kolloquium über Sprachwandel und seine bestimmenden Faktoren, Bochum.

Wurzel W.U., 2001, Flexionsmorphologie und Natürlichkeit. Ein Beitrag zur morphologischen Theoriebildung, 2. Aufl., Berlin.

Žylko F.T., 1958, Hovory ukrajins'koji movy, Kyjiv. 